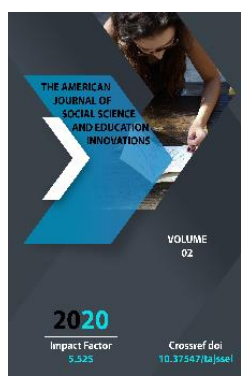

Copyright: Original content from this work may be used under the terms of the creative commons attributes 4.0 licence.

\section{Adaptation Of Students To The Conditions Of Educational Institution}

Dilrabo Inatovna Mukumova

Associate Professor Of "Pedagogy, Psychology And Teaching Methods", Phd In Pedagogical Sciences, Tashkent Institute Of Irrigation And Agricultural Mechanization Engineers, Uzbekistan

Feruza Nigmatovna Umarova

Senior Lecturer Of The English Department, Tashkent Institute Of Irrigation And Agricultural Mechanization Engineers, Uzbekistan

Sevara Bakhodirovna Yarova

Independent Researcher Of The Department Of Pedagogy, Psychology And Teaching Methodology, Tashkent Institute Of Irrigation And Agricultural Mechanization Engineers, Uzbekistan

\title{
ABSTRACT
}

Adaptation of students to the conditions of the educational institution, to the mode of its work is a prerequisite for determining the success of student learning at any professional educational institution. The most important condition for the emergence and development of a professional orientation, and then the formation of a specialist, is an interest in special subjects. If a student has aroused interest in the subject, this is the merit of the teacher.

\section{KEYWORDS}

Success of achievement, student adaptation from traditional positions, the principle of access to education.

\section{INTRODUCTION}

The effectiveness of the process of adapting students to the conditions of the educational institution, to the mode of its work is a prerequisite for determining the success of student learning in any professional educational institution.

If we consider the student's adaptation process from traditional positions, then as a 
managed process, it includes three components: didactic, socio-psychological and professional. This is a single process, passing in three stages:

\section{MATERIAL AND METHODS}

The first stage of adaptation refers to the period when the student is still dominated by the ideas about the forms and methods of education in college that he received at school. During this period, the student's adaptation is especially difficult due to the "inattention" of the lecturer to him, the quantitative uncertainty of the material to be learned, the need to synthesize lecture materials, textbooks, and the need to work independently.

The second period of adaptation is associated with the strengthening of student status and the transition to specialization. At this stage, the student feels confident, shows a sense of belonging to the group, interest in subjects of a special cycle.

In the third period of adaptation, the student begins to form a professional psychology (begins to think like a future specialist). His professional attitudes pass the first testing in practice, where the student's romantic ideas about both the chosen profession and his own level of readiness for it disappear.

\section{RESULTS AND DISCUSSION}

The most important condition for the emergence and development of a professional orientation, and then the formation of a specialist, is an interest in special subjects. If a student has aroused interest in the subject, this is the merit of the teacher. The breadth of erudition, the originality of the presentation of the material allows students to correctly navigate in the subject and overcome difficulties encountered in the process of cognitive activity.

Among students of II and III courses accepted to college on the basis of basic general education, a survey was conducted to identify students' assessment of success in achieving the level of compulsory training. Answering questions, students noted that the purpose of the lesson is clear only $60 \%$, students rarely participate in group discussions, $45 \%$ of students are able to analyze and evaluate the quality of their work, $70 \%$ of students note a favorable climate in the classroom. Diagnostic studies that were conducted in other educational institutions showed that the drop in student performance in comparison with school is due to many factors:

1. A large amount of educational information and the low ability of many students to work independently.

2. A large workload and inability of students to correctly allocate time and assimilate material at the right level.

3. The lack of teachers' own knowledge and psychological characteristics of first-year students and the problem in establishing partnerships between students and teachers.

4. Small life experience, low level of personal responsibility and independence in the behavior of students who came to study from the countryside, lack of psychological and domestic comfort in a student hostel.

For faster adaptation of students in an educational institution, it is necessary to set out educational material taking into account the age characteristics of students. In pedagogy, there is the principle of access to education, which follows from the 
requirements developed by centuries-old teaching practice, on the one hand, the patterns of age development of students, the organization and implementation of the didactic process in accordance with the level of students' development on the other.

The principle of accessibility is based on the following patterns:

1. The availability of training is determined by age characteristics and depends on the individual characteristics of students [9].

2. The availability of training depends on the organization of the educational process, the teaching methods used by the teacher and is associated with the conditions of the learning process.

3. The higher the level of mental development of students and their stock of ideas and concepts, the more successfully they can move forward in the study of new knowledge.

4. The gradual increase in learning difficulties and training to overcome them positively affect the development of students.

5. Training at the optimal level of difficulty has a positive effect on the pace and effectiveness of training, the quality of knowledge.

In the course of attending teacher classes, I found out what teaching methods teachers use and whether they are effective. Teaching methods are methods of collaboration between the student and the student, the organization of the student's cognitive activity, leading the latter from ignorance to knowledge, from inability to skill and allowing him to learn the specific content of education [10].

The method of oral presentation of the material (story, explanation, lectures, instruction) is present in all teachers in the classroom, but we saw a particularly good and accessible presentation of the material in the classroom, L.Ya. Agapova, T.T. Reshetnikova, O.Ya. Rukhlova, and some the teachers' presentation of the material is monotonous, not emotionally colored.

Discussion of the studied material (conversation, classroom class, seminar), discussion of the work done, repetition and consolidation of new material, good activity of students we saw in the classes Agapova L.Ya., Reshetnikova TT, Nesterova VA, Grigoryeva OA, Perevalova OF. This method stimulates the creative activity of students, focusing them on further work [11].

Independent work in the classroom is present in almost all teachers. Students consolidate and repeat the learned material when doing independent work, learn to draw conclusions, activate their cognitive activity, control their knowledge and apply the knowledge gained with specific examples.

\section{CONCLUSIONS}

Some teachers (Popova O.N., Nesterova V.A., Bogdanova S.B.) apply a personality-oriented approach to teaching students, this method makes it possible to involve all students in the creative work, the teaching brings a joyful sense of success and mental development. The teacher plays the role of the educator, and he, along with the students, goes to a creative knowledge of the subject. Each student in each lesson receives an assessment of their work.

As a result of the analysis of the student survey, the analysis of the lessons attended and the students' proposals, I suggest: 
1. Use a variety of forms and teaching methods using game and information technologies, seminars, and excursions.

2. Motivate the cognitive activity of students through a clear statement of the purpose of the lesson, psychological preparation of students for the perception of new material.

3. The content of the material should be accessible taking into account the age characteristics of students.

\section{REFERENCES}

1. Aleksandrov, MA The significance of sociocultural activities in the process of social adaptation of students // Secondary vocational education of students.-2012.№7.-P.45-46.

2. Ball.G.A. The concept of adaptation. / Questions of psychology. 1989, No.1, p. 9.

3. Vasilieva S.A., Kopeina N.S. Psychological identity as a condition for successful adaptation of students to the teaching staff // Modern problems of applied sociology and social psychology in labor collectives. Abstracts of reports. L .: Publishing house of the Leningrad University 1984 - S. 332.

4. Zakharova, G.M. Adaptation of students of the first year of study // Specialist. - 2010. No. 9. - S.21-22.

5. Winter. I.A. Key competencies as an effective and targeted basis of the competency-based approach in education. M .: Issled. Center for Quality Training Issues, 2004

6. Petrova N.I. The level of students' selfactualization and their socio-psychological adaptation // Psychological Journal. 2003. No3. - S.116-120.
7. Solovtsova E. Adaptation during the training of a profession // Public Education. 2004. No. 9.- S.202-207.

8. Scratch TP, T. A. Ulrich, I. V. Nikulin "Effective organization of curatorial activity", Perm State Publishing House. those. University, 2010.147 s.

9. Rustamiy, S. (2018). Typological peculiarties of science of balaghah, rhetoric and stylistics. The Light of Islam, 2018(1), 16.

10. Rustamiy, S. A. (2020). Content of components of the science balagat. ACADEMICIA: An International Multidisciplinary Research Journal, 10(10), 1332-1337.

11. Arthurs, L., \& Templeton, A. (2009). Coupled collaborative in-class activities and individual follow-up homework promote interactive engagement and improve student learning outcomes in a college-level Environmental Geology course. Journal of Geoscience Education, 57(5), 356-371. 